\title{
Sustainability Assessment of the Tanjung Priok Port Cluster
}

\author{
Armand Omar Moeis ${ }^{1 *}$, Fenny Desriani ${ }^{1}$, Arry Rahmawan Destyanto ${ }^{2}$, Teuku Yuri Zagloel ${ }^{1}$ \\ Akhmad Hidayatno ${ }^{1}$, Aziiz Sutrisno ${ }^{3}$ \\ ${ }^{1}$ Department of Industrial Engineering, Faculty of Engineering, Universitas Indonesia, Kampus UI Depok, \\ Depok 16424, Indonesia \\ ${ }^{2}$ Faculty of Technology, Policy, and Management, Delft University of Technology, 2626BX Delft, the \\ Netherlands \\ ${ }^{3}$ School of Innovation Sciences, Eindhoven University of Technology, 5600 MB Eindhoven, the Netherlands
}

\begin{abstract}
A seaport attracts firms to it; such firms are often complementary and find ways to interact with one another, forming port clusters. The growth and decline of these clusters largely depend on government policies. Large port clusters have more economic activity but are also characterized by negative externalities, such as air pollution. This study investigates the dynamics and sustainability of the Tanjung Priok port cluster. System dynamics are used to examine the issue, and port cluster sustainability is assessed by modeling the dynamics of the system over a 20-year timespan. The growth of a port cluster has been found to positively influence the regional economy and the level of employment while also damaging the environment. This study investigates further the impact of an alternative port cluster development program (namely a free trade policy) and shore power system (SPS) program policies on the sustainability of a port cluster. The model indicates that when a free trade policy and an SPS program are implemented in tandem to maximize the economy and reduce environmental damage, they provide additional benefits.
\end{abstract}

Keywords: Economy of port city; Port cluster; Sustainable port; Shore power system; System dynamics

\section{Introduction}

The largest port in Indonesia for cargo traffic is Tanjung Priok, and its trend of growth is upward, especially for container cargo. This port has attracted many firms to locate near it. The government of Indonesia provides a special area as an option for these firms to do business, called the Nusantara Bonded Zone (Kawasan Berikat Nusantara/KBN, Jakarta, Indonesia). According to KBN, the state-owned enterprises that together administer the zone, it is "a certain territory within the customs area of Indonesia which has incentives specifically [for] the suspension of import duties and other state levies" (KBN Persero, 2016). Together, these firms form a so-called port cluster. De Langen (2003) defined a cluster as "a population of geographically concentrated and mutually related business units, associations and public (or private) organizations centered around a distinctive economic specialization" (p. 10). Clusters that form around seaports and are made up of firms that engage in port-related activities are called port clusters (Haezendonck, 2001).

The firms in a port cluster contribute to the economy by giving wages to their 
employees and paying their due taxes. Furthermore, when many firms establish plants and offices close to a seaport, besides bringing more jobs, they also contribute by increasing port throughput. These contributions are dependent on the fact that a port is a cluster of economic activities (de Langen and Haezendonck, 2012) through which a varied range of products is shipped. However, besides benefitting the economy, a port cluster also causes environmental damage because the number of firms in a port cluster increases and the use of port equipment intensifies the need for both land and marine vehicles. The associated fuel combustion contributes to emissions of carbon dioxide $\left(\mathrm{CO}_{2}\right)$ and sulfur dioxide ( $\left.\mathrm{SO}_{\mathrm{x}}\right)$ that reduce air quality around the seaport. These air pollutants affect public health.

We could establish behavioral possibilities and progressive variable effects if we consider a port cluster as a complex system consisting of many interrelated actors, the understanding of which would involve many disciplines, such as those focusing on ports, economics, trade, and the environment (Grösser, 2017). In this regard, a more holistic view is needed to provide a better understanding of the underlying structure and causal relationships between the elements influencing port cluster development. Such a holistic view would provide better insights for policymakers to assess the impact of the Tanjung Priok port cluster in terms of its economic and environmental performance as well as its sustainability. Nevertheless, research addressing this issue is insufficient.

This study aims to investigate the dynamics and sustainability of the Tanjung Priok port cluster as the basis for assessing the feasibility of existing policies in improving the sustainability of this port cluster. This study uses the system dynamics approach (Sterman, 2000; Hidayatno et al., 2015; Yuliawati et al., 2015) incorporated with the policy analysis framework (Thissen and Walker, 2013) to model a port cluster system and analyze how it affects the economy, society, and the environment. For this purpose, two policies will be examined, namely the port cluster development program (free trade zone policy) and the shore power system (SPS). These two policies are chosen for their effectiveness in accelerating economic growth and significantly reducing air pollution. In doing so, this study enriches the literature in maritime logistics and sustainable development in a broader sense. In practice, this research sets the stage for the application of a sustainability assessment framework of a port cluster.

\section{Literature Review}

Ports have changed from being transport nodes into logistics hubs; in this role, they are determining factors for supply chains and logistics (Pettit and Beresford, 2009), especially in facilitating international trade (Panayides et al., 2015). This role benefits a port's regional economy (Wu et al., 2016) and employment (Seo and Park, 2018), which are aligned with port throughput (Wildenboer, 2015).

For several years, port throughput has been used as an indicator of port performance because it reflects the competitiveness of a port (Tongzon and Heng, 2005). However, this performance indicator cannot sufficiently measure the direct, indirect, or induced externalities of a port (de Langen and Visser, 2005). A performance indicator has been proposed to fill this gap, namely the value added generated in the port region (Haezendonck, 2001). The sum of the value added by the population, including expenses, depreciation, and profit before taxes, is used to measure this factor (de Langen, 2003). The population here is limited to the member port cluster's organizations.

The term "cluster" was first introduced by Porter (2000) to indicate "geographic concentrations of interconnected companies, specialized suppliers, service providers, firms in related industries, and associated institutions (e.g., universities, standards agencies, trade associations) in a particular field that compete but also cooperate" (p. 15). Clusters 
that form in the vicinity of a port and core activities that are relevant to cargo shipment are called port clusters (de Langen, 2003; Haezendonck, 2001).

The analysis of port clusters can be developed further. So far, empirical methods have been used to conduct this analysis (de Langen, 2003; Korcis, 2011; de Langen and Haezendonck, 2012), as well as input-output methods (Danielis and Gregori, 2013). However, port clusters consisting of port-related firms form a complex system that needs to be analyzed in relation to this fact. System dynamics is used to analyze complex systems. As the analysis undertaken here aims to produce recommendations for the government on port development strategies that promote sustainability, a system dynamics analysis that can account for the dynamics of a system is needed. The analysis also aims to provide modeling that will address uncertainties in policy (Pruyt, 2013). The present study is conducted to address these gaps.

\section{Methodology}

Several steps must be taken to develop a system dynamics model. Grösser (2017) described six steps in this process: (1) selection of the dynamic problem; (2) conceptualization; (3) formulation; (4) scenario and policy analysis; (5) selection of policies and implementation planning; and (6) implementation (Figure 1). Steps one to five form a loop here. This study only follows the first four steps. The selection of policies, implementation planning, and implementation were not included.

The primary data used in this study were gathered and validated through interviews and focus group discussions with different stakeholders ranging from academia and government (Tanjung Priok Port Authority, Ministry of Transport) to the port and logistics industries. The interviews were held in mid-2018. Secondary data were gathered mostly from the literature and government reports.

The Tanjung Priok port cluster, the selected case in this study, is located in North Jakarta. The port is jointly operated by the state-owned company PT Pelindo II, Hutchison Port Holdings, Port of Singapore Authority, NYK Line, Mitsui \& Co., and several mediumsized local terminal operators in several separate concessions (Wibowo et al., 2015). The port handles more than $50 \%$ of Indonesia's trans-shipment cargo traffic. It has a total capacity of about eight million twenty-feet equivalent units, ranked as the 22nd busiest container port in the world. The Tanjung Priok basin area covers 424 hectares, and its total land area is 604 hectares. The port dimension has a total length of over 12,380 meters and contains 81 berths. Furthermore, the port has 21 warehouses covering 101,972 square meters, whereas the total of its total open storage is $1,995,074 \mathrm{~m}^{2}$. The Tanjung Priok's breakwater is $8,456 \mathrm{~m}$ long, and the channel is $3 \mathrm{~km}$ long (150 meters wide with a depth of 10 meters). In terms of connectivity, the port has a rail connection used by trains for loading and unloading and that can connect to locations across Java.

\subsection{Model Conceptualization}

In model conceptualization, the modeler determines the scope of the project by selecting the variables that can generate the necessary behavior over time graphs. The analyses conducted in this study use modeling and simulation. The development of a conceptual model is an essential step in modeling and simulation. A conceptual model describes the system under study and guides the process of modeling and simulation.

Figure 1 shows the conceptual model or system diagram of the port cluster system. This diagram is useful for depicting the key elements of a client-centered problem formulation (Thissen and Walker, 2013). It illustrates the factors that can influence the outcome of a system under study. The output indicator necessary for this study is derived from the concept of sustainability development. The three aspects of sustainability 
development are economic development, social development, and environmental protection.

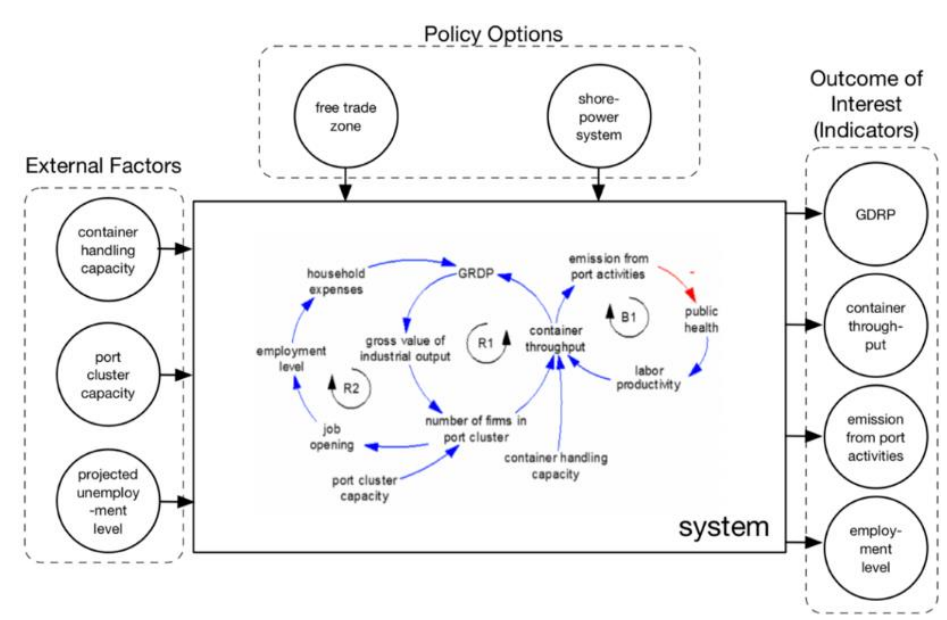

Figure 1 Conceptual model of the port cluster system (adapted from Thissen and Walker (2013))

The gross regional domestic product (GRDP) of Jakarta Province, its employment level, and the emissions produced by the port are chosen as the output indicators for those aspects, respectively. Container throughput is chosen for comparison to economic contribution. The important factors for this study are divided into two: policy alternatives, which can be controlled sources of problems, and external factors, which are not controllable (Thissen and Walker, 2013).

\subsection{Model Formulation}

\subsubsection{Causal loop diagram}

This model uses qualitative and quantitative sub-models. The qualitative model is formed in a causal loop diagram (CLD). A CLD can be used to capture the feedback dependency among variables (Pruyt, 2013). Figure 2 depicts the CLD of the port cluster system under study. The arrows indicate causal relationships. The + signs indicate positive causal relations, and the - signs indicate otherwise.

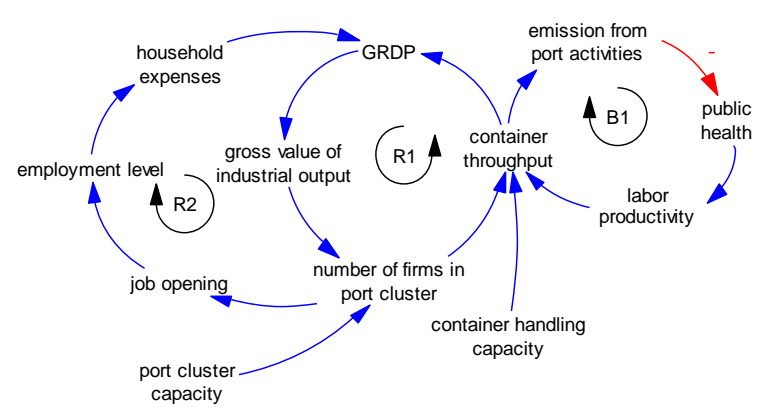

Figure 2 Causal loop diagram of the port cluster system

R1 is a self-reinforcing loop that models improvements in the GRDP and the development of the port cluster through container throughput. This growth is limited by port cluster and container handling capacity. R2 is another self-reinforcing loop that models increases in the GRDP caused by the port cluster and expressed by household expenses, which increase with the increasing number of firms in the port cluster. This loop signifies continuous growth but is also limited by port cluster capacity. B1 is a balancing or 
self-correcting loop, which can act to counteract change. As the container throughput increases, emissions from port activities also increase. However, this increase is balanced with decreases in public health that lead to low labor productivity, eventually reducing container throughput 2.

\subsubsection{Stock and flow diagram}

\section{a) Economic Sub-model}

The main stock in the economic sub-model is the GRDP. Here, an expenditure approach is used to calculate the GRDP. In Figure 3, the GRDP stock is increased through the flow of the GRDP at year $t$ and decreased by the flow of the GRDP at year $t-1$. The value for the GRDP at year $t$ value is obtained from the natural growth of the GRDP, household consumption, and the contribution to the GRDP from container export activities. The equation for this relationship is as follows:

$$
\begin{aligned}
& \text { GRDP at year } t=(G R D P *(1+\text { 'natural growth of GRDP') *34\%) +'household consumption' + } \\
& \text { 'GRDP contribution from export activities'. }
\end{aligned}
$$

The GRDP contribution from container export converts the value from export activities to the GRDP. After the data provided by the Statistical Planning Agency of Indonesia were calculated and the data from KBN were obtained, the total contribution of household consumption and export activities to the GRDP is $66 \%$. The difference of that from the total is $34 \%$, which represents the contribution of other sectors.

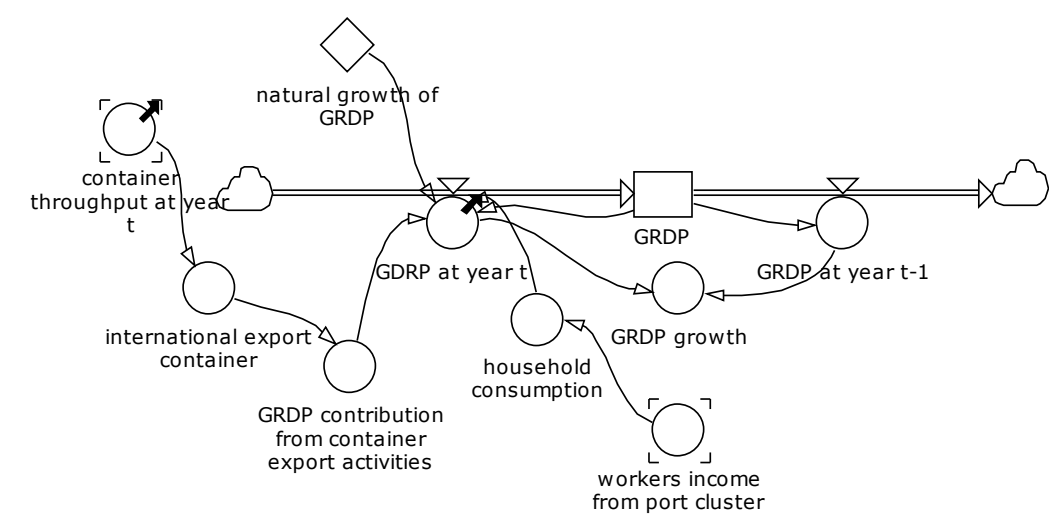

Figure 3 Structure of economic system

\section{b) Port Operations Sub-model}

The port operations sub-model modeled container throughput in the port cluster (Figure 4). The container throughput value is obtained from the accumulation of the flow of container throughput at year $t$ and reduced by the flow of container throughput at year $t-1$. The value for container throughput at year $t$ is obtained from the growth rate of container throughput excluding the port cluster, international container exports from the port cluster, and the container handling capacity for year $t$. This relationship is represented in the following equation:

container throughput at year $t=$ MIN ('container handling capacity for year $t$ '; ('container throughput '*(1+'growth rate of container throughput excludes port cluster')) - $\left(1,77 \% \%^{*}\right.$ ('container throughput*(1+growth rate of container throughput excludes port)) + international export container from port cluster'.

Data obtained from KBN indicate that the number of firms in the port cluster is increasing. However, this is not large enough to indicate anything about overall container 
throughput over the course of a year. The port cluster contributes $1.77 \%$ only to the total container throughput. Nevertheless, this contribution will increase if the cluster develops. The agglomeration-economies sub-model (Figure 5) shows increases in the number of firms in the cluster as a result of economic growth. Regression analysis is used to obtain the relationship of economic growth with the addition of a company. The relationship is represented in the following equation:

$$
\begin{aligned}
& \text { expected number of additional firms from GRDP growth }=\text { FLOOR }(3,67+ \\
& 14,8^{* \prime} G R D P \text { growth'). }
\end{aligned}
$$

Although the number of additional firms is expected to increase with the growth of the GRDP, the real addition of new firms is limited by the available space for firms. The equation for new firms is as follows:

$$
\begin{aligned}
& \text { new firm = FLOOR ((MIN ('expected number of additional firms from GRDP } \\
& \text { growth'; 'available space for firm')). }
\end{aligned}
$$

The main stock in the workforce sub-model is the total workers in the port cluster. This stock is obtained from the successive addition of new workers in the port cluster, the numbers for which are taken from new firms and the workforce demand per firm in the port cluster (Figure 6). The relationship is represented in the following equation:

$$
\text { new workers in port cluster }=\text { 'workforce demand per firm in port cluster' *'new firm'). }
$$

\section{c) Environmental Sub-model}

Port operations involve the operation of vessels, trucks, and cargo-handling equipment, which require fuel combustion that emits pollutants, namely carbon dioxide $\left(\mathrm{CO}_{2}\right)$, sulfur oxide $\left(\mathrm{SO}_{\mathrm{x}}\right)$, and black carbon $(\mathrm{BC})$. These are the pollutants examined here because of their high concentration in the air around the port. $\mathrm{A}$ high $\mathrm{CO}_{2}$ concentration in the air can cause restricted activity days (RADs), which include days spent in bed, days missed from work, and other days when activities are significantly restricted as a result of illness (Ostro, 1994). Changes in the concentration of particulate matter 10 micrometers or less in diameter will change the RAD per person per year (Ostro, 1994), with a coefficient of change of 0,0575 (Figure 7).

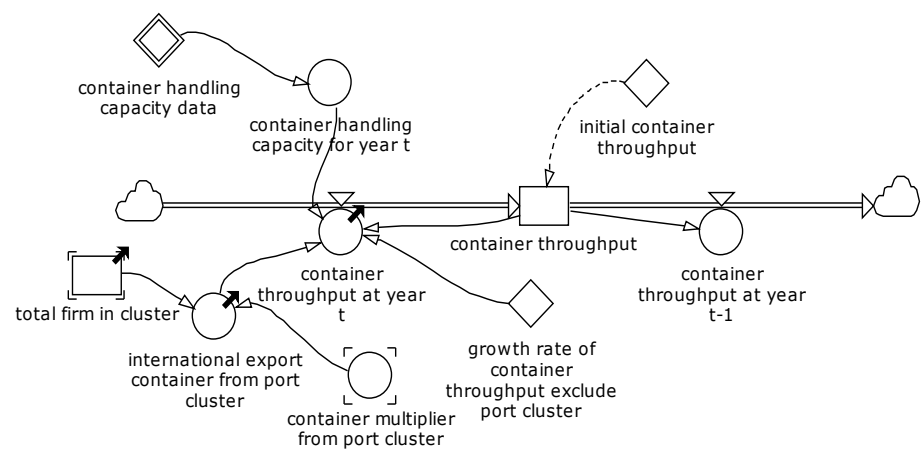

Figure 4 Structure of port operations

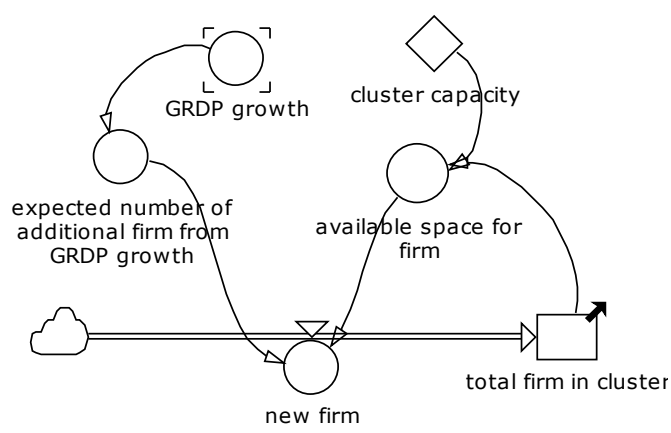

Figure 5 Structure of agglomeration economies

\subsection{Model Validation and Testing}

The model is tested for its validity using several model testing methods, as discussed by Sterman (2000). First, model boundary and structure assessment tests are conducted. This is done to determine whether all important variables for attaining the objectives of the simulation are within the limits of the model. Second, the equations used in the model 
are examined to check the consistency of dimensions. Third, to assess the acceptability of Euler integration, the integration method selected, an integration error test is performed. This was done by running the model on three time scales: 1 year, 180 days, and 90 days. The results of the test show no significant change in the result of the simulation when the time step is changed; therefore, the model is assessed to be valid. Finally, a behavior reproduction test is performed to check whether the system behavior suits the expected results. Table 1 shows that the difference between the real and the model GRDP is only $2 \%$, on average, and it is $9 \%$, on average, for container throughput.

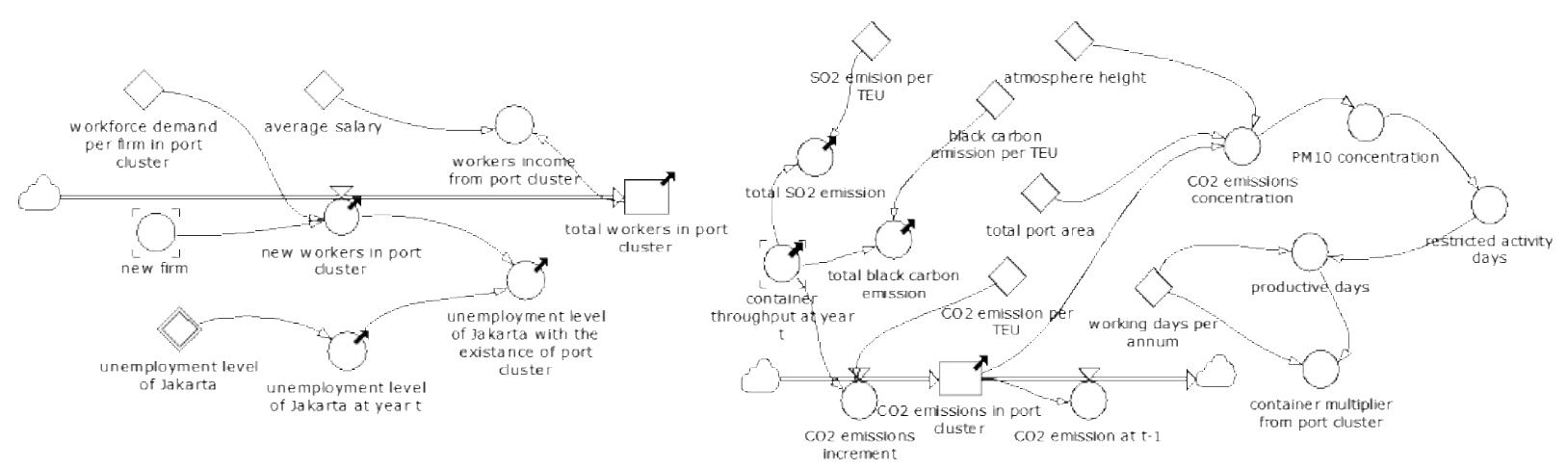

Figure 6 Structure of the workforce

Figure 7 Structure of environmental concerns

Table 1 Model testing behavior reproduction test

\begin{tabular}{lccccc}
\hline \multicolumn{1}{c}{ GRDP (year) } & \multicolumn{1}{c}{2012} & \multicolumn{1}{c}{2013} & 2014 & 2015 & 2016 \\
\hline Real (in million IDR) & $11,203,869$ & $11,888,426$ & $12,595,787$ & $13,239,432$ & $13,999,375$ \\
Model (in million IDR) & $12,331,974$ & $12,680,481$ & $12,927,966$ & $13,141,416$ & $13,345,096$ \\
Container Throughput (year) & 2012 & 2013 & 2014 & 2015 & 2016 \\
Real (in TEUS) & $5,830,000$ & $5,893,262$ & $5,709,889$ & $5,201,118$ & $5,445,571$ \\
Model (in TEUS) & $5,895,183$ & $6,034,054$ & $6,181,837$ & $6,334,537$ & $6,491,169$ \\
\hline
\end{tabular}

GRDP: Gross Regional Domestic Product, IDR: Indonesian Rupiah, TEUS: twenty feet equivalent unit(s)

\section{Results and Discussion: Base Case and Policy Analysis}

The results are presented in three conditions: base case analysis, the alternative Jakarta port cluster program (free trade zone policy), and the SPS program. The free trade zone and SPS policies are tested in the model to determine their effects on the sustainability of the port cluster because these two policies are under the control of the Indonesian government in the port development scheme.

\subsection{Base Case Analysis}

The model in the base case analysis is run on historical data and projection by the authorities. The projected variables are the container handling capacity and unemployment in Jakarta. The growth rate of the Jakarta economy and the growth rate of container throughput are obtained from historical data.

Figure 8 shows the results of simulation for the base case analysis. The development of the port cluster is marked by the arrival of increasing numbers of companies in the shipping sector and by their positive impact on the economy and society. The behavior over time of the GRDP and workers in the port cluster, the numbers for both tend to increase year over year, indicate positive impacts. This result is consistent with that of Bai and Lam (2015) in their study of the Taiwan Straits that the formation of a regional port cluster stimulates economic growth. The benefit to the economy of a port cluster comes 
from exporters and consumers (de Langen and Haezendonck, 2012), as the development of the port cluster triggers an increased volume of international shipping and trade. These increases in trade and shipping volume are followed by job openings; therefore, port cluster development may reduce unemployment, which was simulated in this study.

Jakarta is well positioned to influence shipping and trade. The demand is affected by the hinterland population. Tanjung Priok serves half of the island of Java, the most populous island in Indonesia, ensuring that the high shipping and trade demand pass through Tanjung Priok. The specific characteristics of Indonesia and Tanjung Priok uncovered by the current study represent the unique contribution of this work. This study analyzes the port cluster of Tanjung Priok using system dynamics as the methodology, enabling the anticipation of the future of the port cluster and its sustainability, along with the results of current actions for the future, called the feedback mechanism.

The factors that induce agglomeration economies are the logistical know-how, land cost, the labor climate, and transport efficiency (Van Klink, 1995). The cheap labor and land availability in Jakarta are strengths that can induce agglomeration economies and should be maintained by the government. Internal competition among companies in the port cluster increases the competitiveness of the port cluster (Haezendonck, 2001); therefore, internal competition should be encouraged. Competition is tighter when more companies are in the port cluster. Barriers to entry in the port cluster must be removed. The last performance variable, heterogeneity of the cluster, entails that the diversity of companies and institutions should be enhanced to improve collaboration and complementary action between firms. This study presents alternative scenarios to the authorities' initial plan.
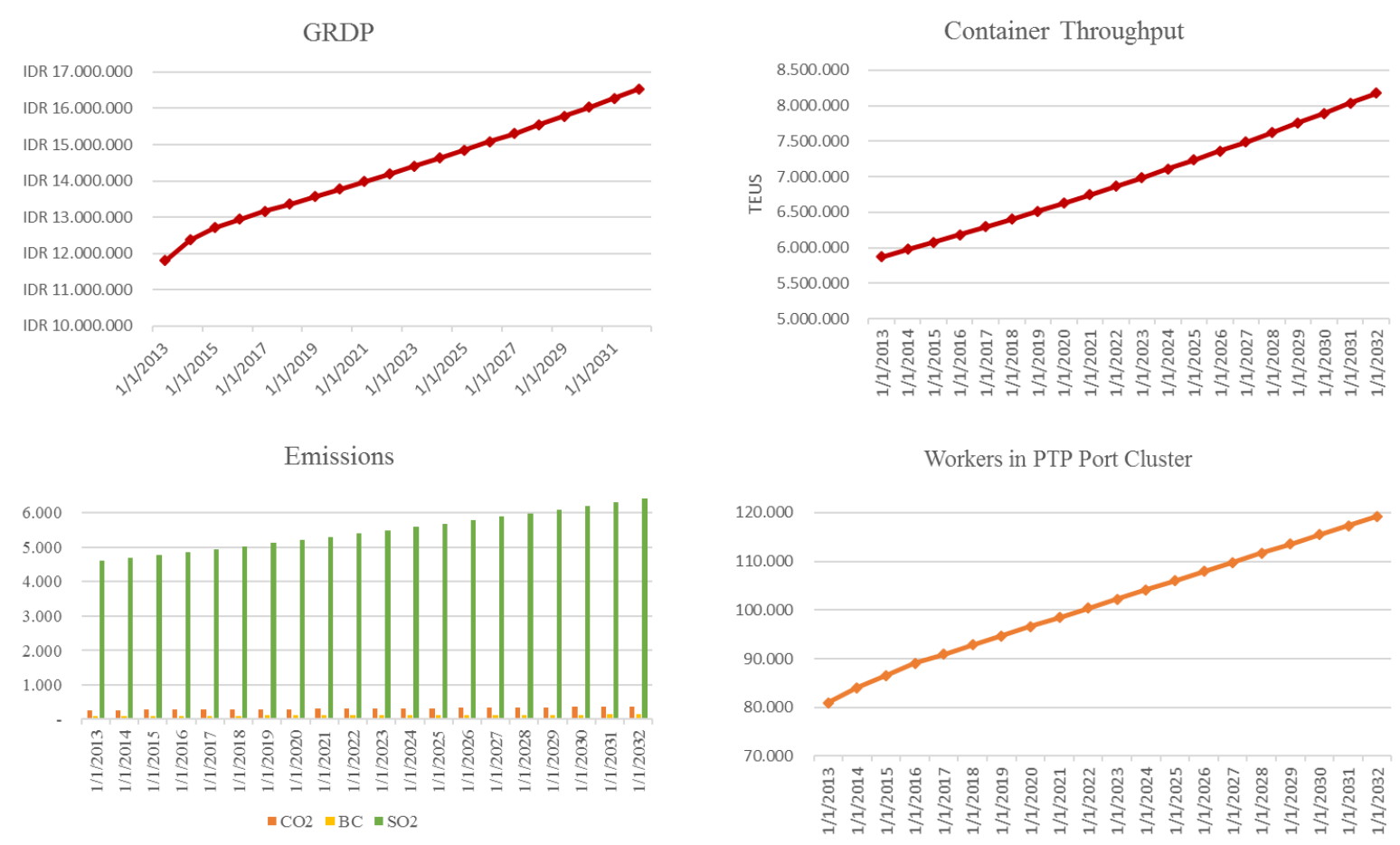

Figure 8 Simulation results for the port cluster of Tanjung Priok regarding its sustainability indicators

\subsection{Policy Analysis}

Three policies were tested in the model. The first is a free trade zone that would allow increased cluster capacity and accelerated company growth in the cluster. The second is an SPS that allows electricity to be channeled to the berths so that a ship does not need to 
turn on its engine, which produces high emissions when it is in the port. The third policy combines a free trade zone and an SPS.

Figures 9 shows that the conditions producing the lowest emissions enable the SPS. Furthermore, the highest economic value comes from the free trade zone, followed by the third policy. The simulation model does not correlate with the impact of applying the SPS to the GRDP value so that value is not affected by the implementation of the SPS. Thus, the most recommended alternative strategy is the third one, as it produces the second-lowest emission value while producing the highest economic value.
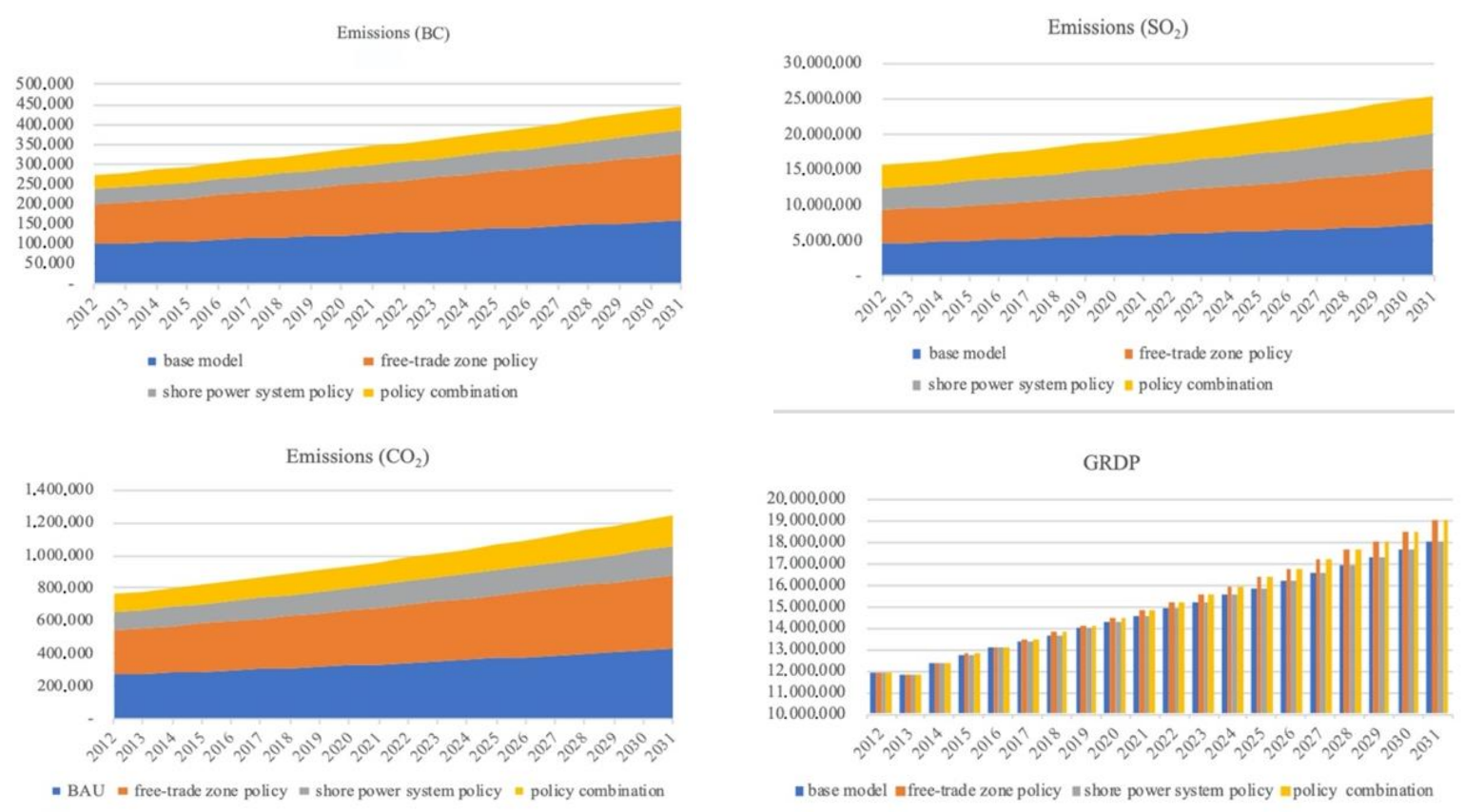

Figure 9 Comparing the emissions $\left(\mathrm{BC}, \mathrm{SO}_{2}\right.$, and $\left.\mathrm{CO}_{2}\right)$ and GRDP of the base model and the three alternative policies

\subsection{Policy Implementation}

We can conclude that by applying simple and straightforward programs such as the SPS, the government/port regulator and other stakeholders could be benefited in two ways. First, the establishment of the SPS will mitigate the current emission level. Second, even if port activities are expanded (through the implementation of a free trade zone policy), thus increasing emission levels, the implementation of this policy combined with the SPS will allow the port to increase economic activities while managing emission levels.

\section{Acknowledgements}

The research was funded by Universitas Indonesia under the Tugas Akhir Doktor (TADOK) research grant (TADOK/122/FT/2018).

\section{References}

Bai, X., Lam, J.S.L., 2015. Dynamic Regional Port Cluster Development: Case of the Ports Accross Taiwan Strait. GeoJournal, Volume 80(5), pp. 619-636

Danielis, R., Gregori, T., 2013. An Input-Output-based Methodology to Estimate the Economic Role of a Port: The Case of the Port System of the Friuli Venezia Giulia Region, Italy. Maritime Economics and Logistics, Volume 15(2), pp. 222-255

de Langen, P.W., 2003. The Performance of Seaport Clusters: A Framework to Analyze 
Cluster Performance and an Application to the Seaport Clusters of Durban, Rotterdam and the Lower Mississippi. Erasmus University Rotterdam. Available Online at https://repub.eur.nl/pub/1133, Accessed on September 28, 2019

de Langen, P.W., Visser, E.-J.J., 2005. Collective Action Regimes in Seaport Clusters: The Case of the Lower Mississippi Port Cluster. Journal of Transport Geography, Volume 13(2), pp. 173-186

de Langen, P.W., Haezendonck, E., 2012. Ports as Clusters of Economic Activity. In: The Blackwell Companion to Maritime Economics, W. K. Talley (Ed.), pp. 638-655. Oxford, UK: Wiley-Blackwell

Grösser, S.N., 2017. Complexity Management and System Dynamics Thinking. In: Dynamics of Long-Life Assets: From Technology Adaptation to Upgrading the Business Model, S.N. Grösser, A. Reyes-Lecuona, \& G. Granholm (Eds.), pp. 69-92. Cham: Springer Open

Haezendonck, E., 2001. Essays on Strategy Analysis for Seaports. Available Online at http://lib.ugent.be/catalog/rug01:000741546, Accessed on October 17, 2019

Hidayatno, A., Rahman, I., Muliadi, R., 2015. Policy Analysis of the Jakarta Carbon Mitigation Plan using System Dynamics to Support Decision Making in Urban Development Options for Policymakers. International Journal of Technology, Volume 6(5), pp. 886893

KBN Persero, 2016. Annual Report PT Kawasan Berikat Nusantara (Persero). Jakarta: KBN Persero

Korcis, A., 2011. The Role of Port Clusters in Theory and Practice. Regional and Business Studies, Volume 3(1), pp. 51-60

Ostro, B., 1994. Effects of Air Pollutants A Method with an Application to Jakarta. Washington DC: World Bank

Panayides, P.M., Parola, F., Lam, J.S.L., 2015. The Effect of Institutional Factors on PublicPrivate Partnership Success in Ports. Transportation Research Part A: Policy and Practice, Volume 71, pp. 110-127

Pettit, S.J., Beresford, A.K.C.C., 2009. Port Development: From Gateways to Logistics Hubs. Maritime Policy and Management, Volume 36(3), pp. 253-267

Porter, M.E., 2000. Location, Competition, and Economic Development: Local Clusters in a Global Economy. Economic Development Quarterly, Volume 14(1), pp. 15-34

Pruyt, E., 2013. Small System Dynamics Models for Big Issues: Triple Jump Towards RealModel Complexity. Delft: TU Delft Library

Seo, Y.J., Park, J.S., 2018. The Role of Seaports in Regional Employment: Evidence from South Korea. Regional Studies, Volume 52(1), pp. 80-92

Sterman, J.D., 2000. Business Dynamics: Systems Thinking and Modeling for a Complex World. Boston: McGraw Hill

Thissen, W.A.H., Walker, W.E. (Eds.), 2013. Public Policy Analysis: New Development. International Series in Operations Research and Management Science, Volume 179, Dordrecht: Springer

Tongzon, J., Heng, W., 2005. Port Privatization, Efficiency and Competitiveness: Some Empirical Evidence from Container Ports (Terminals). Transportation Research Part A: Policy and Practice, Volume 39(5), pp. 405-424

Van Klink, H.A., 1995. Towards the Borderless Mainport Rotterdam: An Analysis of Functional, Spatial and Administrative Dynamics in Port Systems. Available Online at http://lib.ugent.be/catalog/rug01:000363347, Accessed on November 6, 2019

Wibowo, R., Hidayatno, A., Komarudin, K., Moeis, A., 2015. Simulating Port Expansion Plans using Agent-based Modelling. International Journal of Technology, Volume 6(5), pp. 864-871 
Wildenboer, E., 2015. The Relation between Port Performance and Economic Development (Literature Review and Case Study of the Hamburg-Le Havre Range). Rotterdam: Erasmus University

Wu, S., Li, K.X., Shi, W., Yang, Z., 2016. Influence of Local Government on Port Investment: Implications of China's Decentralized Port Governance System. Maritime Policy and Management, Volume 43(7), pp. 777-797

Yuliawati, E., Hadiwardoyo, S.P., Susantono, B., Tjahjono, T., 2015. System Dynamics Model for Airport Characterization in Hub-and-Spoke Networks. International Journal of Technology, Volume 6(5), pp. 733-742 